\title{
Antibacterial Activity of Lannea coromandelica Extract
}

\author{
Hartati $^{1}$, Syamsuddin ${ }^{2}$, Hilda Karim ${ }^{3}$, Halifah Pagarra ${ }^{4}$ \\ \{hartati@unm.ac.id ${ }^{1}$, bsyamsuddin@gmail.com² ${ }^{2}$ hilda.karim@unm.ac.id ${ }^{3}$, halifah.pagarra@unm.ac.id ${ }^{4}$ \}
}

Biology Department, Faculty of Mathematics and Natural Sciences, Universitas Negeri Makassar 1,2,3,4

\begin{abstract}
The aim of this research was to determine the antibacterial activity of Lannea coromandelica extract. The klika of $L$ coromandelica was extracted by wet and dry method using ethyl acetate and ethanol $70 \%$ that acquired 4 types of extracts namely ethanol extract $70 \%$ of wet klika Kayu Jawa (KJBE70\%), extract ethanol 70\% of dry klika Kayu Jawa (KJKE70\%), ethyl acetate extract of dry klika Kayu Jawa (KJKEA), and extract of wet klika Kayu Jawa (KJBEA). Extracted by maceration, and then examined their antibacterial activity. The results from this research shown that all extracts have an antibacterial activity to inhibited bacteria growth which includes Escherichia coli, Staphylococcus aureus, Pseudomonas sp., and Vibrio parahaemolyticus.
\end{abstract}

Keywords: Lannea coromandelica, Antibacterial activity, Extract

\section{Introduction}

Kayu Jawa (Lannea coromandelica) is a plant of the Anacardiaceae family, a tropical tree and grows wildly and hence it is available in various places. L. coromandelica is spread in various regions, namely the Himalayas (Swat-Bhutan), Assam, Burma, Indo-China, Ceylon, Andanan Island, China, and Malaysia [1]. L. coromandelica is also widely distributed on the island of Sulawesi, especially in the South Sulawesi region. L. coromandelica is not only used as a hedge and fodder plant, but has been empirically used by the people of South Sulawesi, especially the Bugis and Makassar tribes as traditional medicine because L. coromandelica has a property that is believed to be very effective in treating internal and external wounds such as mouth sores, toothache, abdominal pain, diarrhea, eye pain, gout, bruises, scratches, and burns. Other uses of L. coromandelica are analgesic, anti-ulcer, and aphrodisiac, the sap is for healing wounds, the leaves treat swelling due to sprains, and have the potential to be used as antioxidants, antimicrobial, and anti-inflammatory [2]. Besides that L. coromandelica contains carbohydrate compounds, steroids, glycosides, terpenoids, tannins, and flavonoids [3].

Antibacterial is a substance or drug to eradicate microorganisms obtained from synthesis or derived from non-organic compounds. [4] in their research on the potential of methanol extract of $L$. coromandelica bark showed that had an antibacterial effect against Staphylococcus aureus bacteria and was thought to contain 5-hydroxymethylfurfural active compounds and 1,2,3-benzenetiolitol antibacterials.

In general, L. coromandelica has been used as traditional medicine, but scientific studies are still limited. Therefore, it has the potential to be scientifically developed as a source of herbal raw materials that are antibacterial due to the presence of bioactive compounds. This study aims to determine the antibacterial activity of $L$. coromandelica extract. 


\section{Methods}

\subsection{Preparation of Sample}

Samples of L. coromandelica were obtained from Pattojo, Soppeng Regency, South Sulawesi. Klika samples were taken and collected as much as $5 \mathrm{~kg}$ then fresh clica was wet sorted, and washed with water then air-dried. L. coromandelica sample consists of 2 types, namely wet and dry samples. L. coromandelica which is taken directly and then shredded is called wet simplicia while dry L. coromandelica simplicia is prepared by shredded and then wrapped in aluminum foil and put in an oven at $40{ }^{\circ} \mathrm{C}$ for a certain time and declared dry after weighing the material until a constant weight is obtained and then blended using a blender until a dry simplicia powder is obtained.

\subsection{Extraction}

Wet and dry L. coromandelica klika was extracted using the maceration method and used 2 types of solvents namely ethyl acetate and $70 \%$ ethanol. Wet and dry L. coromandelica klika samples were weighed as much as 350 grams, put into each jar and soaked with each solvent until simplicia was submerged then covered with aluminum foil that had been perforated with occasional stirring. The solvent is replaced every 1 x 24 hours and is repeated 3 times. The soaked sample is filtered using a whatman filter paper to produce pulp and macerate. Macerate was concentrated using Rotary vacuum evaporator at a temperature of $40{ }^{\circ} \mathrm{C}$ to obtain $70 \%$ Ethanol extract of wet L. coromandelica Klika (KJBE70\%), Ethyl Acetate extract of wet $L$. coromandelica Klika (KJBEA), Ethanol extract of $70 \%$ dry L. coromandelica klika (KJKE70\%), Dry L. coromandelica Klika Ethyl acetate extract (KJKEA)

\subsection{Antibacterial Activity}

The antibacterial activity test of the L. coromandelica klika extract was carried out by observing the inhibition zone using the diffusion method by means of wells. Each petri dish contains 1 sample with 3 different concentrations as well as positive and negative controls. Samples used were KJBE70\%, KJKE70\%, KJBEA, and KJKEA. Tests using the bacteria Staphylococcus aureus, Escherichia coli, Vibrio parahaemolyticus, and Pseudomonas sp. and each treatment was repeated three times. L. coromandelica klika extract with a volume of $10 \mu 1$, negative control (DMSO), and positive control (tetracycline concentration of $2.5 \times 10-3 \mathrm{mg} /$ $\mu \mathrm{l})$ were injected into Agar Nutrient medium wells. The treated petri dishes were incubated in an incubator at $37^{\circ} \mathrm{C}$ for 24 hours. Furthermore, the measurement of the inhibition zone diameter was measured using the calipers in millimeter $(\mathrm{mm})$.

\subsection{Statistical Analysis}

Antibacterial activity data were statistically analyzed by using analysis of variance (ANOVA) at a significance level of $\alpha=5 \%$ then continued with Tuckey's further tests using SPSS (Statistical Package for Social Science) version 22. 


\section{Results and Discussion}

\subsection{Yield of Klika Kayu Jawa (Lannea coromandelica)}

The highest extract results obtained from the maceration process of $350 \mathrm{~g}$ of the sample are KJKE70\% of $20.09 \mathrm{~g}$, KJBE70\% of $18.22 \mathrm{~g}$, KJBEA at $10.05 \mathrm{~g}$ and KJKEA at $6.18 \mathrm{~g}$. The yield of each extract was $5.74 \%, 5.21 \%, 2.87 \%$, and $1.76 \%$, respectively. A comparison of yield results from the wet and dry $L$. coromandelica extract can be seen in Table 1

Table 1. The yield of extract $L$. coromandelica.

\begin{tabular}{ll}
\hline Extract & Yield (\%) \\
\hline KJBE70\% & 5.21 \\
KJBEA & 2.87 \\
KJKE70\% & 5.74 \\
KJKEA & 1.76 \\
\hline
\end{tabular}

\subsection{Antibacterial Activity}

Antibacterial activity of various concentrations of $L$. coromandelica extract was indicated by the presence of a clear zone around the well. The clear zone around the well is a diffusion area of the extract which inhibits bacterial growth. Inhibition Zone Diameter of all extracts can be seen in Table 2, Table 3, Table 4 and Table 5.

The results showed that KJBEA extract was the extract with the highest antibacterial activity compared to other extracts, this was because KJBEA extract contained phenolic compounds that had the ability to interfere with bacterial metabolism so that bacterial growth could be inhibited. In accordance with a phytochemical screening of $L$. coromandelica extract has secondary metabolites namely flavonoids, saponins, and tannins. This is consistent with the opinion of [5] which states that polar extract compounds can easily penetrate the cell walls of gram-negative bacteria due to the hydrophilic group. In addition, according to [6] the cell wall of Gram-negative bacteria contains a protein group called porin which forms hydrophilic pores in the outer membrane layer of the cell so that polar compounds can more easily penetrate the cell wall. flavonoids as antimicrobials by damaging the permeability of bacterial cell walls, microsomes and lysosomes [7].

The results showed that the 5\% KJKEA extract was more sensitive to inhibiting the growth of gram-positive bacteria, namely $S$. aureus than gram-negative bacteria, this was because KJKEA extract had terpenoid compounds which belonged to non-polar compounds, terpenoids could inhibit the autolysin enzyme, thereby affecting cell growth, cell division, and the timing of the formation of peptidoglycan. This is in accordance with the opinion of [8] suggesting that gram-positive bacteria ( $S$. aureus) are more sensitive to non-polar compounds due to the basic components of gram-positive cell wall compilers are peptidoglycan and one of the constituents is alanine amino acids which are hydrophobic (non-polar) so that it is easily penetrated by nonpolar compounds.

The type of solvent used affects the antibacterial activity of $L$. coromandelica Klika extract. Semi-polar ethyl acetate solvent is more optimal for extracting antimicrobial compounds because it can dissolve more compounds. This is presumably because ethyl acetate has 
hydrophilic and lipophilic properties so that the polarity becomes optimum and the antimicrobial substances obtained are maximal [9].

Table 2. Inhibition Zone Diameter of KJBE70\%.

\begin{tabular}{llllc}
\hline \multicolumn{1}{c}{ Experiment } & \multicolumn{3}{c}{ Inhibition Zone Diameter (mm) } \\
& E. coli & S. aureus & Pseudomonas sp. & V. \\
& & & & $7,00 \mathrm{a}$ \\
& & $7,00 \mathrm{a}$ & $7,00 \mathrm{a}$ & \\
Negative Control & & & & $11,82 \mathrm{~b}$ \\
(DMSO) & $7,00 \mathrm{a}$ & $11,31 \mathrm{~b}$ & $15,00 \mathrm{c}$ & $12,31 \mathrm{~b}$ \\
KJBE70\% 5\% & $7,00 \mathrm{a}$ & $12,99 \mathrm{~b}$ & $16,51 \mathrm{~b}$ & $14,16 \mathrm{~b}$ \\
KJBE70\% 10\% & $7,00 \mathrm{a}$ & $14,15 \mathrm{~b}$ & $17,85 \mathrm{~b}$ & $35,72 \mathrm{a}$ \\
KJBE70\% 15\% & $38,88 \mathrm{a}$ & $40,23 \mathrm{a}$ & $36,57 \mathrm{a}$ & \\
Positive Control & & & & \\
\hline
\end{tabular}

Table 3. Inhibition Zone Diameter of KJKE70\%.

\begin{tabular}{lllll}
\hline Experiment & \multicolumn{3}{c}{ Inhibition Zone Diameter (mm) } \\
& E. coli & S. aureus & Pseudomonas sp. & V. parahaemolyticus \\
\hline Negative Control & $7,00 \mathrm{a}$ & $7,00 \mathrm{a}$ & $7,00 \mathrm{a}$ & $7,00 \mathrm{a}$ \\
(DMSO) & & & & \\
KJKE70\% 5\% & $7,00 \mathrm{a}$ & $7,00 \mathrm{a}$ & $10,58 \mathrm{~b}$ & $7,00 \mathrm{a}$ \\
KJKE70\% 10\% & $7,00 \mathrm{a}$ & $7,00 \mathrm{a}$ & $12,15 \mathrm{~b}$ & $10,98 \mathrm{~b}$ \\
KJKE70\% 15\% & $7,00 \mathrm{a}$ & $7,00 \mathrm{a}$ & $13,90 \mathrm{c}$ & $11,61 \mathrm{~b}$ \\
Positive Control & $38,71 \mathrm{a}$ & $40,70 \mathrm{a}$ & $36,69 \mathrm{a}$ & $37,95 \mathrm{a}$ \\
\hline
\end{tabular}

Table 4. Inhibition Zone Diameter of KJKEA.

\begin{tabular}{lllll}
\hline Experiment & \multicolumn{3}{c}{ Inhibition Zone Diameter (mm) } \\
& E. coli & S. aureus & Pseudomonas sp. & V. parahaemolyticus \\
\hline Negative Control & $7,00 \mathrm{a}$ & $7,00 \mathrm{a}$ & $7,00 \mathrm{a}$ & $7,00 \mathrm{a}$ \\
(DMSO) & & & & \\
KJKEA 5\% & $7,00 \mathrm{a}$ & $11,99 \mathrm{~b}$ & $7,00 \mathrm{a}$ & $7,00 \mathrm{a}$ \\
KJKEA 10\% & $7,00 \mathrm{a}$ & $10,32 \mathrm{~b}$ & $7,00 \mathrm{a}$ & $7,00 \mathrm{a}$ \\
KJKEA 15\% & $7,00 \mathrm{a}$ & $10,97 \mathrm{~b}$ & $7,00 \mathrm{a}$ & $7,00 \mathrm{a}$ \\
Positive Control & $38,53 \mathrm{a}$ & $41,14 \mathrm{a}$ & $39,03 \mathrm{a}$ & $39,40 \mathrm{a}$ \\
\hline
\end{tabular}

Table 5. Inhibition Zone Diameter of KJKEA.

\begin{tabular}{lllll}
\hline Experiment & \multicolumn{3}{c}{ Inhibition Zone Diameter (mm) } \\
& E. coli & S. aureus & Pseudomonas sp. & V. parahaemolyticus \\
\hline Negative Control & $7,00 \mathrm{a}$ & $7,00 \mathrm{a}$ & $7,00 \mathrm{a}$ & $7,00 \mathrm{a}$ \\
(DMSO) & & & & \\
KJKEA 5\% & $12,39 \mathrm{a}$ & $14,40 \mathrm{ab}$ & $18,43 \mathrm{c}$ & $17,50 \mathrm{bc}$ \\
KJKEA 10\% & $12,75 \mathrm{a}$ & $16,49 \mathrm{~b}$ & $18,55 \mathrm{c}$ & $18,67 \mathrm{c}$ \\
KJKEA 15\% & $14,08 \mathrm{a}$ & $16,41 \mathrm{~b}$ & $19,88 \mathrm{c}$ & $20,14 \mathrm{c}$ \\
Positive Control & $42,50 \mathrm{~b}$ & $41,83 \mathrm{~b}$ & $37,73 \mathrm{a}$ & $40,15 \mathrm{ab}$ \\
\hline
\end{tabular}




\section{Conclusion}

Antibacterial activity test results showed that $L$. coromandelica all extracts have the antibacterial activity to inhibited bacteria test growth (Escherichia coli, Staphylococcus aureus, Pseudomonas sp., and Vibrio parahaemolyticus. The L. coromandelica klika ethyl acetate extract (KJBEA) had the highest antibacterial properties and inhibited the growth of all tests of bacteria, while the dry $L$. coromandelica klika ethyl acetate extract (KJKEA) had the lowest antibacterial properties and only inhibited the growth of Staphylococcus aureus bacteria.

Acknowledgments. The authors gratefully acknowledge the financial support by the Ministry of Research and Higher Education Indonesia and also to Universitas Negeri Makassar (UNM) for the use of laboratory instruments.

\section{References}

[1] Avinash, Kumar Reddy: Pharmacological Investigations on the standardized leaf extratsof Lannea coromandelica (Hout.) Merr. Journal Indian. (2004).

[2] Tiwari, Kumar., Kaur Mandeep,. Kaur Gurpreet., \& Kaur Harleem: Phytochemical Screening and Extraction: A Review. Internationale Pharmaceutica Sciencia, Vol. 1: issue 1. (2011).

[3] Manik, M.A., Wahid, S.M.A., Islam A. Pal., \& K.T. Ahmed: A Comparative Study of the Antioxidant, Antimicrobial and Thrombolytic Activity of the Bark and Leaves of Lannea coromandelica (Anacardiaceae). International Journal of Pharmaceutical Sciences and Research, Vol. 4(7), E-ISSN: 0975-8232, P-ISSN: 2320-5148 (2013).

[4] Syamsurya, Ahmad A., Firdaus: Potensial Of Methanol Extracts The Stem Bark Lannea coromandelica (Houtt). Merr. Against Staphylococcus aureus and analysis of The Main Secondary Metabolites. Ind J. Chem.Res, 4(1), 362-366. (2016)

[5] Moat A.G., J. W. Foster., \& M. P. Spector: Microbial Physiology Fourth Edition. New York: WileyLiss (2002)

[6] Franklin T, G.A, Snow:.Biochemistry of Antimicrobial Action. London: Chapman and Hall.(1989).

[7] Cushine, T. P., dan A. J. Lamb: Review Antimicrobial Activity of Flavonoids. International Journal of Antimicrobial Agents, Volume 26, 343-356. (2005)

[8] Alberth H. Chan, Jeff Wereszczynskia, Brendan R. Amer, Sung Wook Yi, Michael E. Jung, J. Andrew McCammon, And Robert T. Cubbi: Discovery of Staphylococcus aureus sortase A Inhibitors using Virtual Screening and the Relaxed Complex Scheme, Chem Biol Drug, 82: 418-428 (2013).

[9] Harborne, J.B.: Metode Fitokimia: Penuntun Cara Modern Menganalisis Tumbuhan. Padmawinata, K., dan I. Sudiro, Penerjemah. Bandung (ID). Institut Teknologi Bandung (1987) 